\title{
UGCG Gene
}

National Cancer Institute

\section{Source}

National Cancer Institute. UGCG Gene. NCI Thesaurus. Code C127917.

This gene is involved in glucosylceramide synthesis. 